DOI: $10.21608 /$ mathj.2020.82095

$$
\text { مجالة البعث في التزبية ومام النفس }
$$

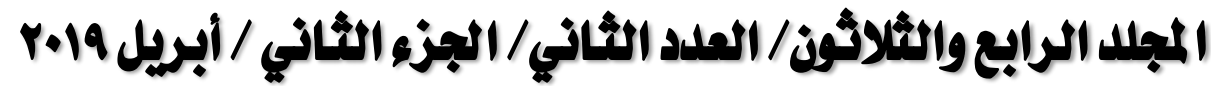

ISSN Print: (2090-0090)

ISSN Online: (2682-4469) 


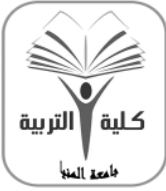

مجلة البعث في التزبية وعلم النفس

كلية التربية - جامعة المنيا

كالية مُمتعدة من الهيئة القومية لشمان جودة التعليم

By

Dr. Omnia Latif Ibrahim Abdel Latif

Lecturer of TEFL at Curricula \& Instruction Dept.

Faculty of Education, Minia University

Abstract:

This study aimed at identifying the effect of using e-Portfolio for developing post graduates' reflective self-assessment, motivation, and achievement. A quasi-experimental pre-post test one group design was employed. An e-portfolio program was developed by the researcher and used with the study group. Participants were thirty males and females. The instruments included a reflective self assessment scale, a motivation scale, and an achievement test. Analysis of data obtained showed that the study group achieved higher in the post administration of the scales, and the achievement test than in the pre-performance. Recommendations and suggestions for further research are presented.

Key Words: e-portfolio - reflective self assessment- achievement

هدفت الدراسة الحالية الى التعرف على اثر استخدام ملف الانجاز الإكتروني فى تنمية التقييم الذاتى التأملي

و الدافعية والتحصيل فى مقرر ( تلدريس الفائقين وبطىء التعلم ) للى عينة من طلاب وطالبات الدراسات العليا تخصص

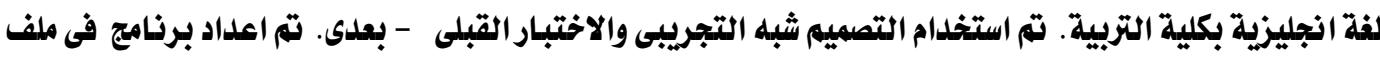

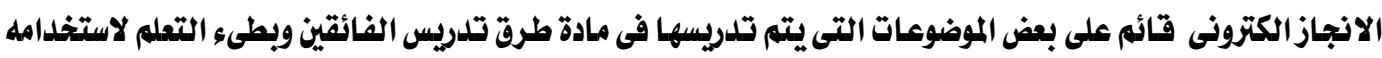
مع عينة الدراسة وعددهم (30) طالبا وطالبة. اشتملت ادوات الدراسة على مقياس التقييي الداتى التاملى ومقياس الدافية وكذلك اختبار لقياس التحصيل. أظهر تحليل النتائج ان عينة الدراسة تفوقت فى التطبيق البعدى للمقياسين والاختبار التحصيلي عن التطبيق القبلى ـ وقدمت الباحثة بعض التوصيات والاقتراحات لبحوث مستقبلية. الكلمات المفتاحية : ملف الانجاز الالكترونى - التقييي الذاتى التاملى- التحصيل 


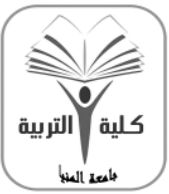

\author{
مجلة البعث في التزبية وعلم النفس \\ كلية التزبية - جامعة المنيا \\ كلية مُعتملة من الميئة القومية لضمان جودة التمليم
}

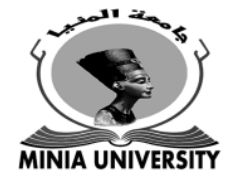

Introduction

The rapidly changing world of work sets new kinds of demands for the studying and working environments. The development of lifelong learning and career management skills, digital competences and $21^{\text {st }}$ century skills (Voogt et al. 2013) becomes an increasingly important task of educators. In order to enhance these skills and competences students need to be more engaged in their learning and assessment processes.

The electronic (e) Portfolios are new concepts in education. They can be easier and adaptable than their paper-based ones. They are flexible and easy to use. Their flexibility has paved the way to a wide range of applications, from development and reflection to assessment and showcasing. However, these applications also introduce complexity into any e-portfolio implementation. The educational potential of e-Portfolios provides users with a comprehensive review of the decision-making that reinforces effective implementation.

Electronic portfolio has been found to promote active learning (Singer-Freeman \& Bastone, 2016) and its pedagogy was recently added as one of the high impact practices in education highlighting the enhancement of deep learning and student success (Eynon \& Gambino 2017). It encourages reflection, academic identity building, future orientation, and personal growth (Singer-Freeman, et al. 2016). However, the benefits of ePortfolio are lost if the learning process is not planned properly with unrelated assignments and a lack of reflective content, or if the students do not get enough support and guidance (Uí Choistealbha: 2018). The use of e-Portfolios has grown significantly with more sophisticated online platforms, and the improvement of technologies has led to research in curriculum design and pedagogy that allows owners of e-Portfolios to demonstrate and explain their learning in a personalized and a student-centered way with constructivist approaches (Kennedy \& Shirley 2011).

Abrami and Barrett (2005) describe an e-Portfolio as: "a digital container capable of storing visual and auditory content including text, images, videos and sound...designed to support a variety of

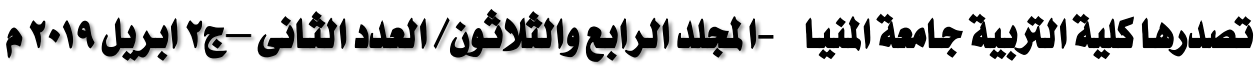

gamel_abdo59@yahoo.com

http://ms.minia.edu.eg/edu/journal.aspx 


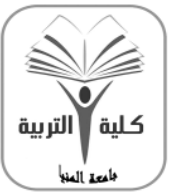

\section{مجالة البحثَ في التزبية ومام النفس \\ كاية التزبية - جامعة المنيا \\ كلية مُعتملة من الميئة القومية لضمان جودة التمليم}

pedagogical processes and assessment purposes". Challis (2005) provides another explanation of an e-Portfolio as being:

- selective and structured collections of information.

- gathered for specific purposes and for showing one's accomplishments and growth.

- stored digitally and managed by appropriate software.

- developed by using appropriate multimedia and customarily within a web environment and,

- retrieved from a website, or delivered by CD-ROM or by DVD.

This was supported by Barrett (2005b) who explains that an ePortfolio is "one that contains work that a learner has collected, reflected on, selected, and presented to show growth and change over time". E-Portfolios are more dynamic than paper-based portfolios. A traditional paper-based portfolio can include samples of students' work and documents that support their achievements (including certificates, assessments, evaluations, observations, field logs, lesson and unit plans, photographs, and collections of best work). E-Portfolios contain materials that can be presented much like a dynamic web page, enabling the creators to include digital photographs, audios, and videos that can demonstrate their abilities as educators. The person viewing this e-portfolio can navigate through it, much like the experience of moving from place to place, or page to page within a Web site. The viewer clicks on hyperlinks to view representations of the learners. This can be done in an efficient, self-directed manner when delivered using computer-based technology. Links to videos of the learner teaching a lesson can be presented.

Topp, Clark, \& Goeman (2002) state that the process (collect, select, reflect) is greatly enhanced through the use of technology in the portfolio development. The e-portfolio uses various media and technology to create, collect and present students' achievements. Hence, it is more important to use it to collect students' works in order to present their great efforts, progress, and self-reflection and to achieve the purpose of sharing. 


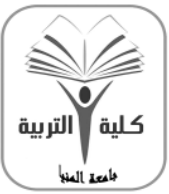

\author{
مجلة البعث في التزبية وعلم النفس \\ كلية التربية - جامعة المنيا \\ كلية مُمتعدة من الهيئة القومية لشمان جودةالتعليم
}

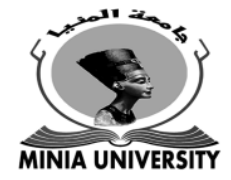

Benefits of Electronic Portiolios:

The benefits of e-Portfolios are discussed by many authors and researchers such as: (Abrami \& Barrett, 2005- Lorenzo \& Ittleson, 2005a- Sherry \& Bartlett, 2005- Wade et al., 2005- and Canada, 2002- Heath, 2005). These benefits are :

Skill development .The creation of an e-Portfolio serves to develop multimedia technology skills as well as more general literacy, communication and problem solving skills.

Evidence of learning. An e-Portfolios encourage "flexible, inclusive, and distributed evidence of learning.

Feedlback. E-Portfolios facilitate the exchange of ideas and feedback. Reflection. E-Portfolios encourage students to reflect on their work and their reasons for choosing certain pieces to be incorporated in their portfolio.

psychological benefits. E-Portfolios foster a sense of pride in their work, a sense of personal accomplishment, and a feeling of satisfaction.

Assessment. E- Portfolios engage students in the frequent evaluation and assessment process.

Artifacts. Many kinds of artifact can be incorporated into ePortfolios. They can integrate text and multimedia elements such as pictures, graphics, and audio and video recordings.

Maintenance. They are easy to maintain, edit and update and because of this are more likely to be constantly revised.

portability and sharing. Whether saved to CD-ROM or to the web, they are easy to carry, to share with others, and to transport into a new system or new working environment.

Access. They are easily accessible by a number of people. Students can work on their portfolios, and supervisors can review and assess them from many different sites.

Audience .They are viewable by a much larger audience including students' peers, supervisors, assessors, parents, employers and others.

organization. They are easy to organize and search. Because of their electronic nature, they can be organized in complex ways, with navigational links connecting ideas and artifacts.

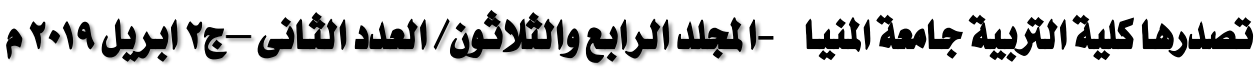

gamel_abdo59@yahoo.com

http://ms.minia.edu.eg/edu/journal.aspx 

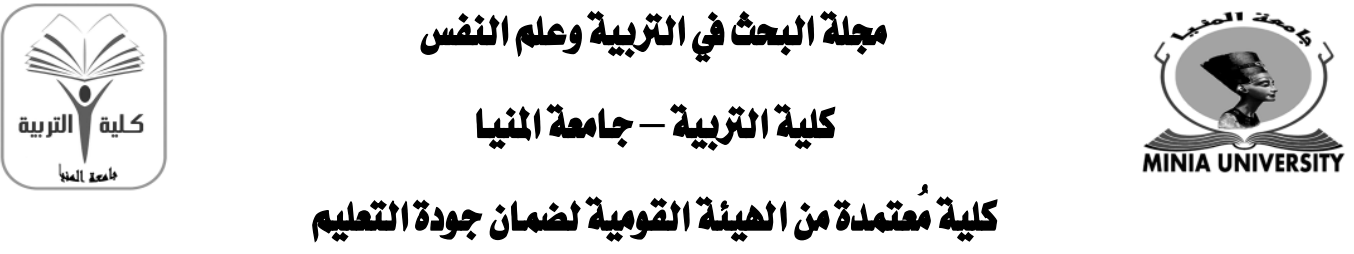

Storage. Because they do not rely on large binders full of paper, they are easy and efficient to store.

cost. They are inexpensive, especially to reproduce, although initial set-up costs in software and equipment may in fact be quite high. privacy. Finally, they can include a privacy feature to protect student work. Access can be limited to only those that students wish to view their work.

Pitts (2001) states that e- portfolios are seen as tools to increase learners' self-awareness, to foster their ability to learn independently and to encourage them to reflect on their own performance. More specifically, according to Andre (2011), eportfolios help to demonstrate and support:

- individual reflective thinking, employment, education and professional and personal development.

- performance based on analysis of previous and current practice.

- performance based on analysis of previous and current knowledge, skills and experience.

- learning based on knowledge acquisition and skill development.

- setting future goals and career direction (based on consideration and analysis of the previous two points)

Advantage of The " $e$ "

Goldsmith (2007) states that "Although the process is possible with paper-based portfolios, the electronic feature is more advantageous. It allows the portfolio owner to keep work over time without keeping individual pieces of paper or files on an individual computer. Any type of digital material can be placed in an e-portfolio, a major advantage in a world where many students are creating digital objects. The " $e$ " makes portfolios available any time and anywhere for both the owners of the portfolios and for those viewing and reviewing them. Their electronic nature also allows portfolios to be genuine, easily available showcases for purposes outside the institution, such as job searches. Students can invite guests to click on a link and review their work online at their leisure". 


\section{مجالح البجثة في التزبية وملم النفس \\ كايلة التزبية - جامعة المنيا \\ كلية مُعتملة من الميئة القومية لشمان جودة التمبيم}

E-Portfolios also allow revision over time. Instead of an assignment being handed in, graded, and then filed away, it can be added to a portfolio and revised, revisited, and reflected on. Constructivism and E-portiolios

E-Portfolios fall within a learning theory known as social constructivism, which proposes, that learning happens most effectively when students construct systems of knowledge for themselves, rather than simply having information presented. Social constructivism also proposes that another cause of effective learning is that it happens in a social context - that is, we construct our knowledge through dialogue and interactions with others. With e-Portfolios, the process of reflection originates as a solo activity, but becomes social through feedback from the student's instructor, peers, mentors, and even family members who respond to and provide commentary on those reflections. (Bass and Eynon ,2009).

Portfolios fully cope with constructivist thought when it involves students in their own education so that they can take charge of their personal collection of work, reflect on what makes some work better, and use this information to make improvements in future work. Students will construct more knowledge when they drive force behind the learning and the teacher promotes the process by helping them "collect, select, reflect, and connect" (Epstein, 2009). Research shows that e-Portfolio pedagogy encourages constructivist approach to teaching, learning, and meaningful assessment.

Constructivist principles such as knowledge building, active and self-directed learning, collaborative learning and practice can all be applied to support e-Portfolio based learning (Ligorio \& Sansone, 2009). Constructivism supports the belief that meaning is constructed by learners, and the nature of the learning activities focus on students having metacognitive control, formative feedback, appropriate motivation, interconnected knowledge, and opportunities for social learning (Biggs \& Tang, 2011). Metacognitive control refers to self- monitoring, reflection, selfassessment, self-management, and lifelong learning. Constructivism learning activities that are possible through the use of e-Portfolios

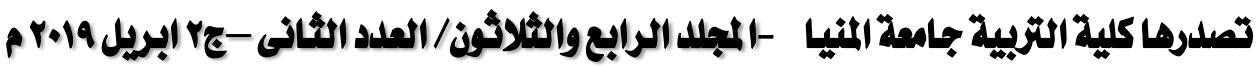




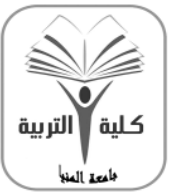

\section{مجالة البحثَ في التزبية وملم النفس \\ كاية التزبية - جامعة المنيا \\ كلية مُعتملة من الميئة القومية لضمان جودة التمبيم}

include: feedback, monitoring, reflection, prior knowledge, studentfocused conceptual change, and self-assessment.

E-Portiolio and Reflective Seli Assessment:

Finley (2012: 22), refers to e-Portfolios as "assignments designed to provide students with opportunities to demonstrate their learning for each outcome as individuals and within groups". Students include evidence of their academic and personal experiences, which they connect to each other through planned reflections. The types of evidence students include: academic, real world, and co-curricular experiences and projects, all of which can be communicated through mixed media. E-Portfolios also allow for the creation of assignments with rubrics that can be used for grading and/or for course assessment purposes (Strudler, and Wetzel, 2011:168). They provide an authentic documentation of professional achievement as an alternative to traditional assessment because they allow students to collect, select and reflect on artifacts that demonstrate their professional competencies (Topp, et al 2002).

Dikici (2009) mentions that portfolios can contribute to lifelong learning beyond school environments. Computer technology allows e-Portfolios to be one career tool for life-long learners. Willis and Wilkie (2009:79-80) say that:

"the ability to capture and store video files, audio files, computer programs, hyperlinked documents and multi-dimensional representations affords a better assessment of student learning and personal growth. $E$ Portfolios allow students to see their progress toward the achievement of their goals, provide visual integration of students' knowledge, skills, and capabilities and provide evidence of students' progressive development during their college careers."

Schneider and Rhodes (2011) explain the impact of portfolio pedagogy on student learning and what can be understood about that learning: " the evolving evidence on portfolios of student work suggests that applying knowledge, integrating learning from multiple sources, and reflecting on the process of learning, its quality, and the outcomes - the how and the why of learning-

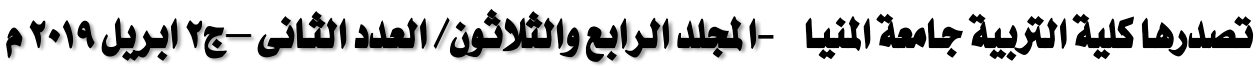

gamel_abd059@yahoo.com

http://ms.minia.edu.eg/edu/journal.aspx 


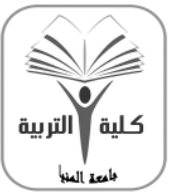

\section{مجالة البحثَ في التزبية ومام النفس \\ كاية التزبية - جامعة المنيا \\ كلية مُتملةة من الميئة القومية لضمان جودةالتمليم}

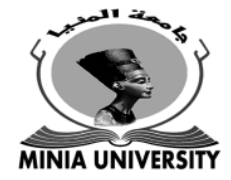

further reinforces student learning"(p.vi). Reflection helps its own unique purposes in the e-Portfolio implementation. As Cambridge (2010:103) wrote, "Almost without exception, scholars agree that the process of reflection that goes into composing an e-Portfolio is central to its effect on learning" Specific to a teacher education setting, portfolios have a variety of purposes: to teach prospective teachers how to be reflective, to assess their readiness to graduate, as part of the process of registering beginning teachers, and as part of teacher education programs (Zeichner \& Wray, 2001). Portfolios can serve to measure achievement for practicum work and to foster reflection on teaching (Smith \& Tillema, 2003). It is by reflecting on the evidence collected in their portfolios that student teachers are able to uncover their strengths and weaknesses, develop an awareness of their teaching and learning achievements, assume responsibility for their own learning, and begin to anticipate their learning needs (Orland-Barak, 2005).

When e-Portfolios for learning, for evaluation and for assessment integrate together in one e-Portfolio framework, learning precedes evaluation and assessment. Therefore, learners must have knowledge and skills and show them by completing tasks and developing products through a variety of class work. Evaluation and assessment of "learning" then takes place within the ePortfolio framework. Indeed, the potential of e-Portfolios is that stakeholders get authentic assessment (Cambridge, 2010) because its pedagogy invites self-assessment for students via their reflections, and curriculum assessment from student reflections. According to Stefani, Mason, and Pegler (2007:75) "authentic assessment must be built upon authentic learning experiences. The e-Portfolio can be supportive here in recording the authentic learning, by allowing students to compile different kinds of evidence of learning". E-Portfolios support a variety of activities related to learning and professional development. They can be used to store and organize information, and allow students to arrange materials for assessment. Similarly, they can be used as a tool to support reflective learning processes. 


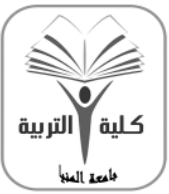

\section{مجالة البحثَ في التزبية ومام النفس \\ كايلةالتربية - جامعة المنيا \\ كلية مُعتملة من الميئة القومية لضمان جودة التمليم}

Barrett (2004) says that "Formative assessment is an essential component of classroom work and that its development can raise standards of achievement more effectively than any other strategy". He explains that assessment for Learning is the process of seeking and interpreting evidence for use by learners and their teachers to decide where the learners are in their learning, where they need to go and how best to get there. To be effectively used to support assessment for learning, e-portfolios need to support the learner's progress.

Barton and Collins (1997) present seven essential features of portfolios that distinguish portfolios from other forms of assessment.

- Portfolios are multi-sourced that provide a variety of evidence of learner competency.

- Authenticity. The multiple pieces of student works included in the portfolio are directly linked to the classroom instruction.

- They are a form of dynamic assessment that allows teachers to capture students' learning process over time.

- Purpose of portfolios is explicitly defined and communicated with students.

- Integration. Students have to show the evidence how they linked knowledge learned in their academic courses to their real-world experiences.

- Student ownership. It requires self-evaluative reflection on the pieces of evidences included in the portfolios.

- It's of multi-purposed nature. Portfolios can be used to evaluate students' achievement, as well as assess the effectiveness of instructions.

Reflection is a vital component of learning and reflective practice is a learning process. The essence of using a portfolio as instructional strategy is to encourage students' reflective learning. Through the facilitation of reflective experiences, students visit, revisit, evaluate, and make decisions about their learning. In order for systematic reflection to become best practice in teacher education, developmental reflective opportunities must be incorporated into teacher education curricula. 


\section{مجالة البحثَ في التزبية وملم النفس \\ كايلة التزبية - جامعة المنيا \\ كليلة مُقتملة من الميئة القومية لشمان جودة التعليم}

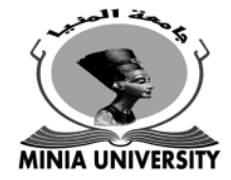

Gordon (2003) states that reflection in portfolios helps students to be reflective learners. They can analyze the evidence of their own learning. However, it requires higher-order thinking skills. Moon (2005) views reflection as a form of mental processing that one uses to achieve an expected outcome. Therefore, it is necessary to provide a framework and guided question prompts to guide students to develop meaningful reflections. Without reflection, a portfolio is merely a compile of works developed over time. Paris and Ayers (1994) state that self-assessment involves reflecting upon the choice made, analyzing the reasons for those choices and stepping back from the active involvement providing the distance they need in order to observe what they were doing. Therefore, reflection can help learners highlight what goal has been achieved, as well as what has not been achieved. Issenberg and McGaghie (2002) explain that the portfolio assessment should be constructive to promote students' development. Lawrence (2017) says that an e-Portfolio is a means to engage in a reflective and collaborative approach to planning, organising and enhancing an individual's learning and work.

According to Tuksinvarajarn and Sojisirikul (2009), portfolios should include interaction and reflection. The first one is the interaction between students and teachers. For example, after students submit their work, teachers have to return the work to the students. The returned work should include the feedback given. The second one is the reflection. Students have to do the self-reflection upon their learning goal, strength, weakness and learning process. Similarly, Plata (2003) proposed that students should be able to use their knowledge and skills to set their learning goal, to use learning strategies effectively, to be aware of their strengths and weaknesses and to monitor their own progress. Hart (2015) presents a model of weblog with Facebook login. It was designed and used as a virtual medium in which students could post their writing works; the drafts, the revised and the final versions. In this way, their works are accessible not only for the teacher and their peers but also for the public. The teacher and students could also write comments as feedbacks for improvement of the drafts. Boulton (2014:375) shows that e-

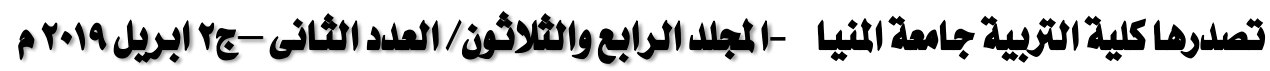

gamel_abd059@yahoo.com

http://ms.minia.edu.eg/edu/journal.aspx 


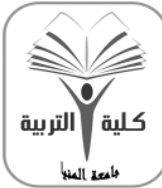

\section{مجالة البحثَ في التزبية ومام النفس \\ كايلة التزبية - جامعة المنيا \\ كلية مُتملةة من الميئة القومية لضمان جودةالتمليم}

Portfolio pedagogy can be used as an alternative method of assessment in that it shows skills and achievements, and reflects and uses appropriate communication modalities. Wray (2007b) encourages constructivist approach to teaching and learning, and created meaningful assessment practices for self-directed learning. Therefore, e-Portfolios are critical instruments for managing each student's academic progress.

E-portiolio \& Motivation

Motivation is considered a basic factor when designing the portfolio. Tuksinvarajarn and Sojisirikul (2009) state that

The integration of technology can be a motivating factor for portfolios, especially if the students can engage in the process of learning, and they have an opportunity to express themselves. The electronic portfolio is not just completing a form on the website, but it must involve individuality, creativity, and ownership.

Barrett (2006) says that learners should be able to feel and to see "themselves" when they look at their e-Portfolios. The information and the work in the portfolio should demonstrate who they are and what they are interested in. Learner ownership is a motivation factor that should not be ignored. Apple and Shimo (2004) have shown that portfolios seem to generate an overall positive response from learners compared to other more traditional forms of evaluation. If some students prefer portfolio assessment, then perhaps portfolios may also encourage a more positive attitude toward learning. Dornyei (2005) suggests that without sufficient motivation learners cannot accomplish their long-term goals. The opposite seems also to be accepted; that with a high degree of motivation even students with a low aptitude can achieve acquisition.

Axton (2012) mentions that most experienced teachers could say that finding ways to motivate students with low levels of interest in a class and finding suitable teaching materials toward that end is both difficult and time consuming, especially if those students appear not to be motivated in learning. This is not to say such students are incapable of learning the material, but rather they may seem to lack the motivation to study.

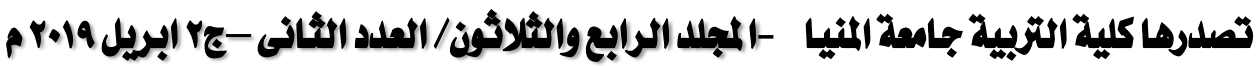




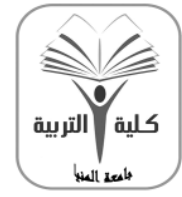

\section{مجالة البحثَ في التزبية ومام النفس \\ كاية التزبية - جامعة المنيا \\ كلية مُعتملة من الميئة القومية لضمان جودة التمليم}

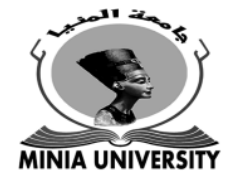

E-Portfolios have been shown to aid students in becoming aware of their own learning styles and strategies and self-reflection. Studies show that learners seem to be motivated to use ePortfolios as a learning tool. Motivation in using e-Portfolios has been studied by researchers; however, one area that has not been touched upon much is that of using portfolios as tools for developing motivation in learning a language. Driessen et al. (2007) also found e-Portfolios to enhance students' motivation.

E-portiolio and Achievement

E-Portfolios help teachers keep track of students' learning process and their achievements. They are effective tools for formative assessment and professional development. Yancey (2001) argues that e-Portfolios are used to analyze and evaluate student works. With the multiple evidences that students provide, portfolios tend to offer the instructor a richer picture of students' achievement. E-Portfolios also provide students an opportunity to do selfevaluation on their work and reflect upon it. They also allow students to participate in peer reviews (Stefani, et al., 2007). They were seen as one form of authentic assessment that was particularly suited to evaluating the application of theory in practice (Green et al 2014).

The purpose of a paper presented by Trevitt, Macduff, and Steed (2013) is to reflect on past experiences working with portfolios for teaching development, and working in online education, to identify factors which will assist them to make valuable advances in e-Portfolio-based education. Research also shows that ePortfolio pedagogy can be used as an alternative method of assessment in that it showcases skills and achievements, and reflects and uses appropriate communication modalities (Boulton \& Hramiak 2012). Boulton $(2014,375)$ encourages constructivist approach to teaching and learning and creates meaningful assessment practices for self-directed learning. Therefore, ePortfolios are effective tools for managing student's academic progress and provide significant advantages because they are easily accessible online and the end users can view them on computers, cell phones or other devices.

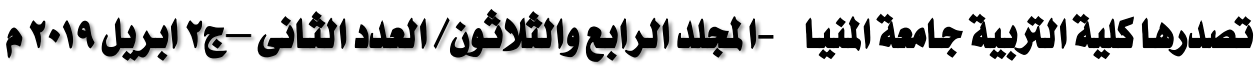




\section{مجالة البحثَ في التزبية وملم النفس \\ كايلة التزبية - جامعة المنيا \\ كليلة مُقتملة من الميئة القومية لشمان جودة التعليم}

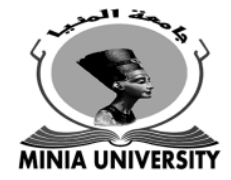

The findings of the above cited studies reveal that the e-Portfolio, the student teachers compile, indicates that they demonstrate knowledge, skills and attitude when compiling specific artifacts for a portfolio. Boulton and Hramiak (2012) argue that ePortfolios are about collecting and compiling evidence of work in electronic format which demonstrates knowledge, skills, attitude and constructive feedback of work that the student teacher submits. Out from the positive outcomes of the studies conducted in university environments, this study which was conducted in an open distance learning environment also shows positive benefits that hopefully e-Portfolios could be used as an empowering tool to enhance student teachers' self-directed learning in a teacher education course.

According to Pegrum and Oakley (2017) e-Portfolios are becoming an increasingly common component of higher education programs, serving as constructivist learning spaces where students can reflect on their learning journeys, on which students can be assessed, and as integrated showcases where they can demonstrate their accomplishments. Pre-service teacher education courses are among the higher education programs where participants are asked to build e-Portfolios which they will be able to continue to expand and develop once they have obtained employment as teachers.

Rowley and Munday (2018) say that e-Portfolios are increasingly being used in universities to help develop self-reflective practitioners, academic teachers and students' need to develop the skills and processes required to implement them.

With reflective thinking, pre-service teachers could critically interpret their teaching practice experiences and make connections among their portfolio goals, relevant evidences from their teaching practice experiences, and their reflections, which help foster their professional learning (Boulton, 2014). The portfolio construction process becomes more productive when there exists regular and ongoing collaboration and interaction between the owners of the portfolios, their instructors, and peers (Chaudhuri \& Cabau, 2017). Supportive feedback resulting in these interactions helps pre-service teachers not only enhance the

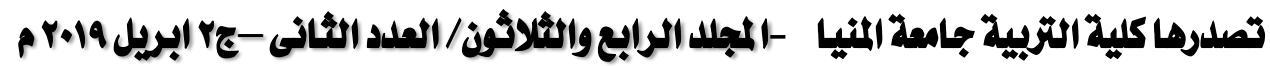

gamel_abdo59@yahoo.com

http://ms.minia.edu.eg/edu/journal.aspx 


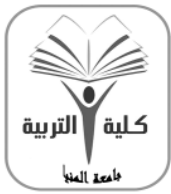

\section{مجالح البحث في التزبية ومعم الثفس \\ كاية التزبية - جامعة المنيا \\ كلية مُعتملة من الميئة القومية لشمان جودة التمبيم}

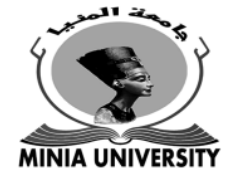

quality of their portfolio artifacts but also advance their learning about teaching, inspiring their reflective thinking on their teaching practice experiences.

Boulton (2014) mentions that the e-Portfolio may serve the purpose of assessment for the pre-service teachers provided that a clear set of assessment criteria is needed to assess their growth in teaching. An advantage of e-Portfolios is that digital information can be collected and organized more easily and that it can be shared through electronic forums. Händel, Wimmer, and Ziegler (2018) investigate the weekly use of a reflective e-Portfolio and its effect on exam performance. Students' use of the e-Portfolio elements as well as their self-reported use of several learning strategies were documented during a 9-week period. Results show that the reported use of cognitive strategies was a significant predictor for exam grade. Finally, students who used the e-Portfolio outperformed their peers without e-Portfolio use on the final exam.

Background of the Problem:

To verify the problem of EFL post graduates' deficiency in reflective self assessment, low motivation, and low achievement, TEFL experienced staff members were informally interviewed to shed light on this issue. They asserted that reflective self assessment, motivation and achievement, though greatly needed for post graduates, were not dealt with seriously from the part of staff members. Students are asked to collect some information about a certain prescribed topic and compile them on paperbased portfolios. When asked to reflect on this material, they could not and mostly feel embarrassed and worried and sometimes refused to share as in most cases they just copied the same material from their colleagues. This state of affairs was more emphasized by reviewing the literature related to these issues. Many authors and research workers emphasized that there has been little research done to investigate the integration of reflective self assessment, motivation and achievement of post graduates. Therefore, this research was hopefully expected to be a promising one to develop post graduates' reflective self assessment, motivation and achievement, through an e-Portfolio program designed by the researcher and used for this purpose.

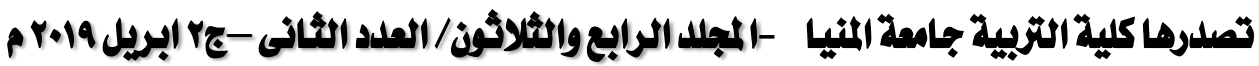




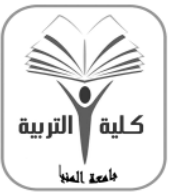

\author{
مجلة البعث في التزبية وعلم النفس \\ كلية التزبية - جامعة المنيا \\ كلية مُعتملة من الميئة القومية لضمان جودة التمليم
}

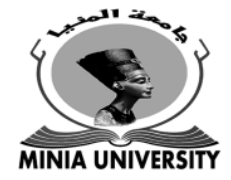

Review of Literature:

E-Portiolio and Reilective Seli Assessment

E-Portfolios promote feedback, reflection, and self-reflection. They possess digital collections of student artifacts and require them to reflect on their learning processes. Therefore, they can contribute to the assessment of students' own products and individual achievement and to the effectiveness of courses, programs, departments, or institutions (Reese \& Levy, 2009). They enhance the reflection of students since students understand their learning and have the "evidence of their capacity for critical thinking, analytic reasoning, and integrative learning" (Rhodes, 2011, p. 5).

Lin (2008) indicates that reflection helps students increase their learning experiences and makes a change in the way they view their learning. Students can develop a sense of purpose and focus through the use of e-Portfolios because upon reflection, they make a comparison between their artifacts and the standards in order to understand and check first whether their artifacts meet the standards or not, and then how and why they meet the standards. It can also assess students formatively in terms of the evaluation of student learning, and summatively in terms of the evaluation of student progress and achievement

(Rhodes, 2011), and it can also help learners become active in the presentation of their learning, so this can motivate them to do their best. Goldsmith (2007) also mentions that e-Portfolios can provide students with individual feedback about their learning, experiences, achievements, and can provide feedback about the effectiveness of their work. Therefore, e-Portfolios can improve students' learning through feedback and reflection, which supports learning and makes them more willing to overcome problems (Gray, 2008). Reflection is at the heart of any evidence submitted in a portfolio and there is much debate as to whether reflection can or should be assessed. It has been suggested that knowing the portfolio will be assessed is a motivating factor for students. Several studies and reviews found that students often see keeping a portfolio as an additional burden and are unlikely to engage in it voluntarily without the stimulus of assessment (Vance et al, 2013).

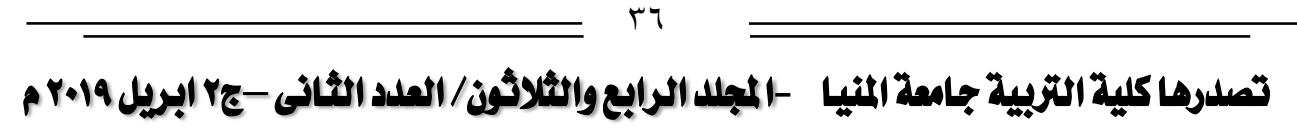




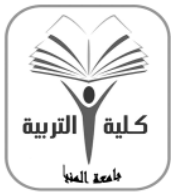

\section{مجالح البحث في التزبية ومعم الثفس \\ كاية التزبية - جامعة المنيا \\ كلية مُعتملة من الميئة القومية لضمان جودة التمليم}

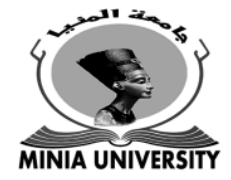

Strivens et al (2009) find that respondents, a number of whom had carried out formal evaluations, gave a range of benefits relating both to student education and improved efficiency. The evaluations from students were equally positive. This work suggests that portfolios can be used successfully for both formative and summative assessment.

However, Murie (2011) suggests that assessment can be detrimental to the fundamental principle of reflective learning which promotes self-awareness and encourages the learner to be honest about their learning and development needs. Some researchers have questioned the value of using the portfolio as an assessment tool, and students may be reluctant to engage in honest, reflective learning if they know their expressed limitations will form part of assessment criteria. Brown (2002:228) reported that developing portfolios 'increased students' understanding of what, why, and how they learned throughout their careers, enhanced their communication and organization skills, and reinforced the importance of reflection in learning". Milman (2005) finds that the constructivist process of developing eportfolios promoted candidate reflection. Candidates examined their beliefs, philosophies, objectives, and purposes for teaching and, in examining and reflecting on them, grew in varying degrees from this reflective process.

E-Portiolio and Motivation

Irie's (2005) results indicate that most students' motivation decreases from the start of the study to the end of the three-year period. One of the possible reasons she offers for this decrease is the nature of English education in Japan. Students are required to enroll in English classes from their first year in junior high school and on through their senior year in high school. The focus of the compulsory English classes is also geared toward passing a number of tests, and then finally preparing students for university entrance exams.

Driessen et al. (2007) find e-Portfolios to enhance students' motivation and to deliver the same quality of content as traditional portfolios. Huang, Yang, \& Chang (2011) investigate the effect of e-Portfolio satisfaction on students' learning

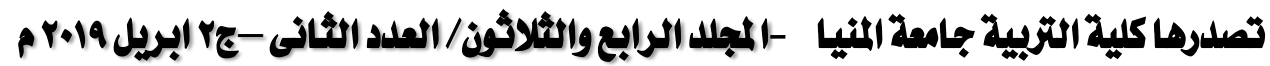

gamel_abd059@yahoo.com

http://ms.minia.edu.eg/edu/journal.aspx 


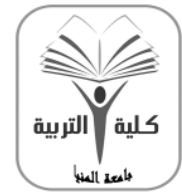

\author{
مجلة البعث في التزبية وعلم النفس \\ كلية التزبية - جامعة المنيا \\ كلية مُعتملة من الميئة القومية لشمان جودة التمليم
}

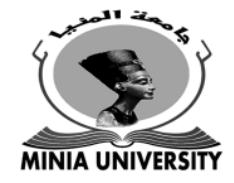

motivation and internet self-efficacy toward the use of e-Portfolio. The findings revealed that there were positive correlations between learning motivation, internet self-efficacy, and e-Portfolio satisfaction. There were also significant differences in learning motivations and in internet self-efficacy between the two groups. Stefanie, Liau \& Liu (2012) examine how student teachers' motivational profile and their experiences of value, enjoyment, and effort are related to their perceptions of the e-Portfolio. Participants were 413 student teachers. Results suggest that students with more self determined forms of motivation and who reported enjoying, valuing, and putting effort into the process were more likely to view e-Portfolios positively.

Gámiz, Arrufat, \&Moya (2016) examine the impact of e-Portfolios on undergraduate learning in higher education. The study analyzed the prospective teacher's perception of use of e-Portfolio examining the variables participation, autonomous learning, and motivation. The results showed no increase in motivation, but they showed an increase in autonomy, especially a progressive increase in the student's online participation in a blended learning context. The results showed a positive correlation between the variables.

The e-Portfolio received a great deal of attention in the educational discourse and is associated with the individualization of the learning process. Unlike traditional forms of examination, such as tests, exams or

essays, assessment methods enable focusing on problem solving strategies and processes as well as a greater insight into the underlying skills of students. In the course of this method, a portfolio in general and an e-Portfolio in particular can be valuable tools.

\title{
E-Portiolio and Achievement
}

A study by Tubaishat and Lansari (2013) focuses on the students' attitudes and opinions towards the usefulness of e-Portfolios to demonstrate achievement of learning outcomes, getting feedback from their instructors, as well as using e-Portfolios as a tool to become active and reflective learners. Study results show that students have a positive attitude towards e-Portfolio to help them

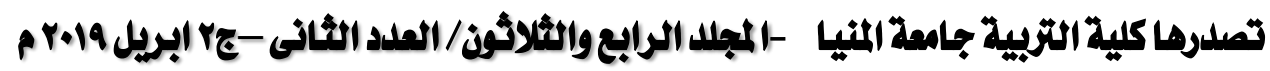

gamel_abdo59@yahoo.com

http://ms.minia.edu.eg/edu/journal.aspx 


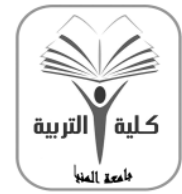

\author{
مجلة البعث في التزبية وعلم النفس \\ كلية التربية - جامعة المنيا \\ كلية مُعتمدة من الميئة القومية لضمان جودة التمليم
}

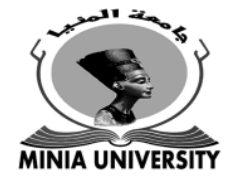

store their work and to document the achievement of specific learning outcomes. Students feel that they improved their learning experiences through the use of reflection. They also believe that using their e-Portfolios allows them to better manage their learning. The study also show that some students actually enjoyed having to develop and maintain their e-Portfolios to show achievement of various learning goals. Finally, as the system encourages the establishment of clear learning goals and expectations, students are taking responsibility to demonstrate that they are achieving their learning goals and faculty are helping students achieve these goals while tracking their progress towards achieving their learning outcomes.

Cowan \& Peacock (2017) present the case for self-managing and self-regulating learners to link their various forms of reflection explicitly, and to do so within an e-Portfolio, in order to support the development of higher-level abilities. They explore the reflective options for self-managed experiential learning, and concentrate upon what three forms of reflection (reflection for,on- and in-action) entail, and could contribute to learning and development. It also addresses how linking previous reflections can contribute to the development of higher-level abilities. An e-Portfolio is taken as a natural and effective location for this integration.

\title{
Conclusion
}

The research into e-Portfolios within language classrooms has been mostly concerned with self-assessment and evaluation of students. There has also been much studies in terms of using ePortfolios as tools for enhancing and developing independent learning. E-Portfolios have been shown to aid students in becoming aware of their own learning styles and strategies and self-reflection. Many studies have shown that learners also seem to be motivated to use e-Portfolios as a learning tool. However, one area that has not been touched upon much is that of using ePortfolios as tools for developing motivation in learning a language. Literature shows that e-Portfolios can be a great resource for both students and teachers as they can facilitate student learning and help students accomplish important learning goals. However, the above studies did not investigate how e-

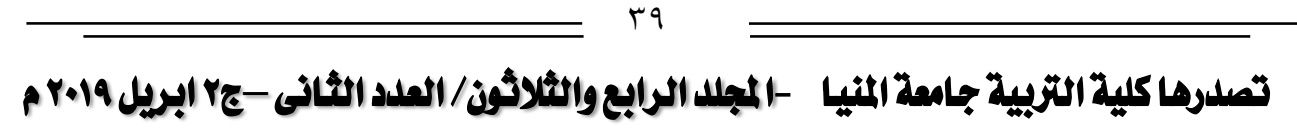




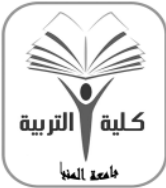

\section{مجالة البحثَ في التزبية ومام النفس \\ كايلة التزبية - جامعة المنيا \\ كلية مُتملةة من الميئة القومية لضمان جودةالتمليم}

Portfolios could be used to help students demonstrate the achievement of learning outcomes which makes this study unique. Statement of the Problem:

In the course of "Methods of Teaching the Gifted and the Slow Learners", used with EFL post graduates, they were not offered enough opportunities to develop their reflective self assessment, motivation or achievement. Therefore, they were in need of developing these goals if they were to be effective teachers. This was the main motive behind initiating the present study. Reviewing the literature on the significance of using e-Portfolios in higher education and particularly with EFL post graduates motivated the researcher to attempt an e-Portfolio program for enhancing their reflective self assessment, motivation and achievement.

objectives of the Study:

The objectives of this study were to:

1. develop reflective self-assessment of participants.

2. develop motivation of participants.

3. develop achievement of participants. Questions of the Study:

The following questions are addressed in this study:

1. Can the use of an e-Portfolio as a tool for reflective self assessment serve as a motivating factor for the post graduates' learning?

2. Can e-portfolio develop post graduates' motivation?

3. Can e-portfolio develop achievement of post graduates?

Hypotheses of the Study:

1. There would be a statistically significant difference (favoring the post performance) between means of scores obtained by the study group on the pre - post reflective self assessment scale.

2. There would be a statistically significant difference (favoring the post performance) between means of scores obtained by the study group on the pre - post motivation scale.

3. There would be a statistically significant difference (favoring the post performance) between means of scores obtained by the study group on the pre - post achievement test.

Significance of the Study

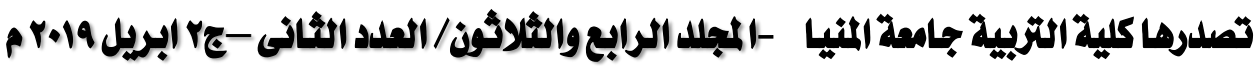




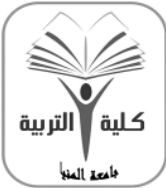

\section{مجالة البحثُ في التزبية ومعم الثفس \\ كايلةالتربية - جامعة المنيا \\ كلية مُعتملة من الميئة القومية لضمان جودة التمليم}

The significance of the present study is represented in the following:

- Helping participants develop their reflective self assessment, motivation and achievement by exposing them to an ePortfolio program.

- Providing participants with an invaluable chance to override the limits of paper based bound knowledge to other sources.

- Course designers and instructors will find the e-Portfolio program useful and effective in teacher preparation programs as an e-Portfolio provides a good chance for both instructor and graduates.

- Contributing to teacher preparation programs by providing a model of a program that deals with reflective self assessment, motivation, and achievement activities.

\section{Delimitations}

1. The study was delimited to (30) post graduate English majors at the Faculty of Education, Minia University in the 1st semester of the academic year 2018 - 2019. It was supposed that the development of reflective self assessment, motivation, and achievement would support them in their long-life learning.

2. Reflective self assessment was limited to four dimensions that were decided and agreed upon by the instructor, staff members, and experts. These dimensions are: Planning, Assessment/ Reflections, Instruction, and Management

3. The achievement test was limited to the topics that were dealt with during the semester in the Methods of Teaching the Gifted and the Slow Learners' course. These topics are:

a- Characteristics of gifted and slow learners.

b- Teaching language skills (listening, speaking, reading, and writing) to gifted and slow learners.

c- Skills of managing the class of gifted and slow learners.

Definition of Terms:

E-portiolio: 


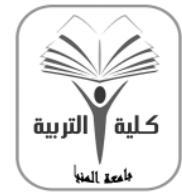

\section{مجالة البحثَ في التزبية ومام النفس \\ كاية التزبية - جامعة المنيا \\ كلية مُتملةة من الميئة القومية لضمان جودةالتمليم}

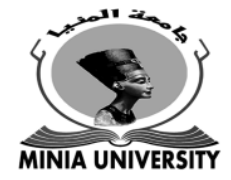

Lorenzo \& Ittelson,( 2005) define e-Portfolio as a digitized collection of artifacts including demonstrations, resources, and accomplishments that represent an individual, group, or institution. Barrett (2011) defines it as an electronic collection of evidence to demonstrate learning over a selected period. Evidence may include photos, videos, research projects, interviews and reflective writing. Lawrence (2017) defines it as a collection of documents that can be uploaded and scanned onto an electronic platform. It is owned and personalised by the individual user to demonstrate reflective learning and competence in their personal and professional development.

Operationally defined, e-Portfolio is "an online collection of artifacts accompanied by reflection that not only helps the participants to understand and extend learning, but invites the reader of the ePortfolio to gain insight about learning and the learner".

Seli Reilection

Yancey (2001) views reflection as a key component of e-Portfolio. She lists seven essential features of e-Portfolios: (1) a collection of work; (2) a selection of work; (3) reflections; (4) presumption of development; (5) diversity of content; (6) a communication tool; and (7) an evaluation tool.

Hilzensauer (2008) defines self-reflection as an ability to relate to one's own strengths and weaknesses, at the same time being able to act critically and, on this basis, to recognize one's own learning difficulties or possibilities.

The researcher adopted the definition of Yancey (2001).

\section{Motivation:}

Ryan \& Deci (2000) define motivation as a need that requires satisfaction. These needs could be wants or desires that are acquired through influence of culture, society, lifestyle, etc. They also define it as one's direction to behaviour, or what causes a person to repeat behaviour, a set of force that acts behind the motives. Motivation has been considered as one of the most important reasons that inspire a person to move forward. The researcher adopted the definition of Ryan \& Deci (2000). Methodology:

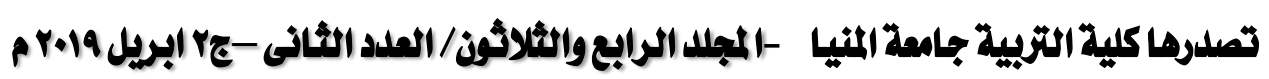




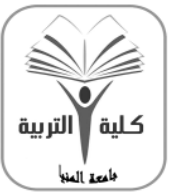

\author{
مجلة البعث في التزبية وعلم النفس \\ كلية التزبية - جامعة المنيا \\ كلية مُمتعدة من الهيئة القومية لشمان جودةالتعليم
}

A quasi-experimental pre-post one group design was employed. An e-Portfolio program was designed by the researcher for developing reflective self assessment, motivation and achievement of the study group. This group followed the (Methods of Teaching the Gifted and the Slow Learners' course). Thirty (30) male and female post graduate English majors enrolled in 2018-2019 academic Year $\left(1^{\text {st }}\right.$ semester) formed the study group. The data of the study were collected by means of a reflective self assessment scale, a motivation scale, and an achievement test. Participants were exposed to an e- Portfolio program. At the end of the program, the same instruments were re-administrated.

Variables of the Study:

Independent Variable: An e-Portfolio program.

Dependent Variables

- Developing reflective self assessment.

- Developing motivation.

- Developing achievement.

The E-Portiolio Program

The e-Portfolio program was designed by the researcher to develop post graduate English majors' reflective self assessment, motivation and achievement. The content of the program was based on the teaching material that they learnt throughout the $1^{\text {st }}$ semester course of (Methods of Teaching the Gifted and the Slow Learners) giving more emphasis on the points of weakness that appeared when piloting the study instruments. A panel of jury members approved its suitability for the objectives and the participants. The program consists of eight sessions. The first session is an orientation one. Each session deals with a certain teaching topic. Students were directed to develop their own eportfolios according to the instructions given by the researcher. Instruments of the Study

\title{
1. The Reflective Seli Assessment scale
}

objective:

The objective of the scale is to identify the level of post graduates' ability to reflect on their own work presented in their e-Portfolio. The scale construction depended on the different topics normally taught in the Teaching the Gifted and the Slow learners course.

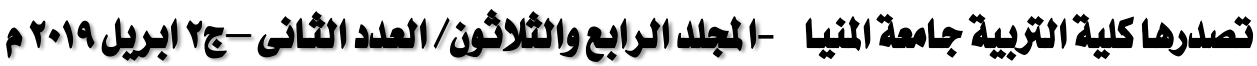

gamel_abdo59@yahoo.com

http://ms.minia.edu.eg/edu/journal.aspx 


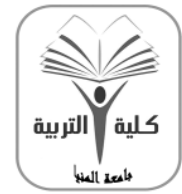

\author{
مجلة البعث في التزبية وعلم النفس \\ كلية التربية - جامعة المنيا \\ كلية مُعتعدة نز الهيئة القومية لشمان جودةالتعليم
}

MINIA UNIVERSITY

These topics include (Characteristics of gifted and slow learners, teaching language skills, and management). The scale has four dimensions (planning, assessment/ reflection, instruction, and management). The total score of the scale is 175 . The rating scale ranged from 5 to 1 , respectively from (Strongly agree, agree, undecided, disagree, and strongly disagree). 30 minutes were assigned for responding to all items. This time was decided on when piloting the program by counting the time taken by each student and then taking the average.

Validity of the scale

Five TEFL specialists approved the suitability and applicability of the scale. They also approved the skills that are needed and should be included in the program. Reliability was computed using testretest method and was found to be $(0.98)$. Internal consistency of each dimension was calculated. The correlation between the score of each dimension and the total score of the scale ranged from $(0.48)$ to $(0.93)$. This indicates that the scale has a high degree of validity. See Table (1).

Table (1)

Internal consistency of the Reflective Self Assessment Scale Correlation Between each Individual Domain and the Total Score (Validity)

\begin{tabular}{r|c}
\hline \hline \multicolumn{1}{c|}{ Dimension } & Correlation \\
\hline 1- Planning & $0.48^{* *}$ \\
\hline 2- Assessment/ Reflection & $0.88^{* *}$ \\
\hline 3- Instruction & $0.93^{* *}$ \\
\hline 4-Management & $0.86^{* *}$ \\
\hline \hline$*$ Significant at 0.01 & total score $=\mathbf{1 7 5}$
\end{tabular}

\title{
2. The Motivation Scale:
}

\section{Objective}

The objective of the scale is to identify the level of post graduates' motivation for e-Portfolios and for teaching before and after implementing the program. The scale was constructed on the basis of the specific objectives included in the program.

Validity

Five jury members of TEFL specialists approved the validity of the scale and its suitability to post graduates. Their suggestions were taken into consideration.

The scale consists of two dimensions: 

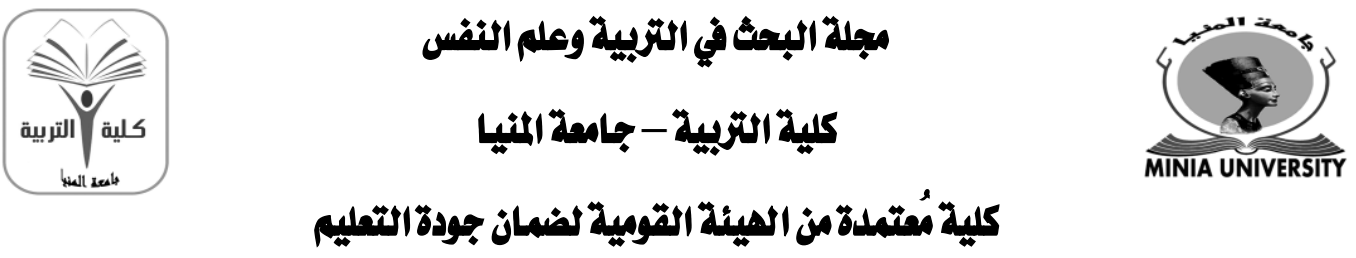

1. Motivation for e-portfolio (10 items).

2. Motivation for teaching (10 items).

The total score of the scale is 100 . Twenty minutes were assigned for responding to all items. Participants were required to indicate their motives towards each statement.

The internal consistency: The correlation between the score of each dimension and the total score of the scale ranged from $(0.87)$ to (0.96). This indicates that the scale has a high degree of validity. See table (2).

Table (2)

Internal consistency of the Motivation Scale Correlation Between Individual Domain and the Total Score (Validity)

\begin{tabular}{c|c|c}
\hline \hline No. & Dimension & Correlation \\
\hline \hline 1 & Motivation for e-portfolio & $* * 0.96$ \\
\hline 2 & Motivation for teaching & $\mathbf{0 . 8 7} * *$ \\
\hline \hline \multicolumn{3}{r}{$*$ Significant at $0.01 \quad$ total score $=100$}
\end{tabular}

Reliability coefficient was done using test - retest method and showed that the reliability of the scale is $(0.97)$. This shows that the motivation scale enjoys a high degree of reliability.

3. The Achievement Test

objective

The test aimed at evaluating the achievement of the participants in the methods of teaching the gifted and the slow learners course. It consists of (30) items; 10 completion items, 10 multiple choice items and 10 short essay questions. These are distributed on three dimensions. These are "Characteristics of gifted and slow learners, teaching language skills, teaching management skills". The total score of the test is (30), one score for each correct answer. Sixty minutes were assigned for responding to the test items.

Validity of the Test

The face validity of the test was judged by TEFL experts. They confirmed the suitability and applicability of the test items.

The internal consistency of the test was found by calculating the correlation between the score of each dimension and the total score. The correlation coefficient was found to be between 0.75 and 0.89 . See Table (3).

Table (3)

Correlation Coefficient between Each Dimension \&

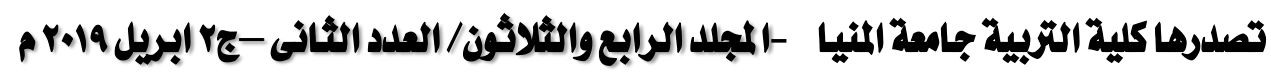

gamel_abdo59@yahoo.com

http://ms.minia.edu.eg/edu/journal.aspx 


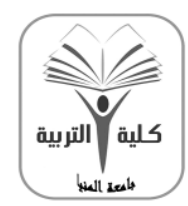

\section{مجالح البجثة في التزبية وملم النفس \\ كاية التربية - جامصة المنيا}

كلية مُعتمدة من الميئة القومية لضمان جودة التمعيم

the Total Score of the Achievement Test

\begin{tabular}{c|c|c}
\hline \hline No & Dimension & Correlation \\
\hline \hline 1 & $\begin{array}{c}\text { Characteristics of Gifted and slow } \\
\text { learners }\end{array}$ & $0.75 * *$ \\
\hline 2 & Teaching Skills & $0.89 * *$ \\
\hline 3 & Management & $0.81^{* *}$ \\
\hline \hline
\end{tabular}

Internal consistency of each item was also calculated. The correlation between the score of each item and the total score of the test ranged from $(0.30)$ to $(0.79)$. This indicates that the scale has a high validity. See table (4).

\section{Table (4)}

Internal Consistency of the Achievement Test Correlation Between Each Individual Question and the Total Score of the Test

\begin{tabular}{c|c|c|c|c|c}
\hline \hline item & $\begin{array}{c}\text { Correlation } \\
\text { characteristics }\end{array}$ & Item & $\begin{array}{c}\text { Correlation } \\
\text { Teaching Skills }\end{array}$ & Item & $\begin{array}{c}\text { Correlation } \\
\text { Management }\end{array}$ \\
\hline \hline 1 & 0.44 & 11 & 0.57 & 21 & 0.30 \\
\hline 2 & 0.58 & 12 & 0.54 & 22 & 0.49 \\
\hline 3 & 0.34 & 13 & 0.50 & 23 & 0.61 \\
\hline 4 & 0.61 & 14 & 0.59 & 24 & 0.65 \\
\hline 5 & 0.42 & 15 & 0.60 & 25 & 0.61 \\
\hline 6 & 0.53 & 16 & 0.48 & 26 & 0.72 \\
\hline 7 & 0.55 & 17 & 0.44 & 27 & 0.79 \\
\hline 8 & 0.65 & 18 & 0.56 & 28 & 0.30 \\
\hline 9 & 0.40 & 19 & 0.57 & 29 & 0,58 \\
\hline 10 & 0.52 & 20 & 0.44 & 30 & 0.39 \\
\hline \hline
\end{tabular}

*Significant at $0.05 * *$ Significant at $0.01 \quad$ total score $=30$

For estimating the reliability of the test, the data obtained were computed. Reliability coefficient was done using test- retest method and the reliability coefficient was found to be $(0.98)$. The Pilot Study:

A pilot study was conducted to estimate the validity and reliability of the instruments. A group of 21 post graduates were randomly selected. Piloting helped to correct unclear and ambiguous items. It helped to determine whether the items in the reflective self assessment scale, the motivation scale and the achievement test were functioning for use in the main study or not. The data collected were prepared, analyzed and interpreted. The instruments were reviewed according to the results obtained. Validity was determined by consulting a panel of experts. The 


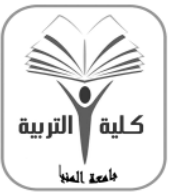

\section{مجالة البحثَ في التزبية ومام النفس \\ كايلةالتربية - جامعة المنيا \\ كلية مُعتملة من الهيئة القوميل لشمان جودة التمليم}

reliability coefficient of the instruments scores was determined by the test-retest method.

\section{Item Analysis}

The effectiveness of each item was determined by analyzing students' responses to the items. This analysis improves the test by discarding ineffective items, and identifying how far the test items are difficult. The item difficulty index ranged from $(0.38)$ to (0.62). See Table (5).

Table (5)

Indices of Difficulty of the Items of the Achievement Test

\begin{tabular}{c|c|c|c|c|c}
\hline \hline Ques. No. & Difficulty & Ques. No & Difficulty & Ques. No & Difficulty \\
\hline \hline 1 & 0.48 & 11 & 0.62 & 21 & 0.58 \\
\hline 2 & 0.53 & 12 & 0.58 & 22 & 0.53 \\
\hline 3 & 0.58 & 13 & 0.53 & 23 & 0.38 \\
\hline 4 & 0.58 & 14 & 0.43 & 24 & 0.48 \\
\hline 5 & 0.58 & 15 & 0.48 & 25 & 0.43 \\
\hline 6 & 0.58 & 16 & 0.48 & 26 & 0.43 \\
\hline 7 & 0.48 & 17 & 0.38 & 27 & 0.38 \\
\hline 8 & 0.58 & 18 & 0.38 & 28 & 0.43 \\
\hline 9 & 0.48 & 19 & 0.53 & 29 & 0.48 \\
\hline 10 & 0.43 & 20 & 0.38 & 30 & 0.53 \\
\hline \hline
\end{tabular}

Pre Testing

\section{A. Pre testing of the Instruments}

The study group was pre tested so as to measure their performance before administering the e-Portfolio program and to identify the degree of improvement in their reflective self assessment, motivation, and achievement.

The Procedures Followed in Implementing The E-Portiolio:

The researcher followed the following steps in carrying out the ePortfolio program:

1- Describing what topics the course (methods of teaching the gifted and the slow learners) would include.

2- Letting participants know what was expected from them throughout the course.

3- Defining course objectives as they were a key component of working with e-Portfolios.

4- Reinforcing that participants were responsible for organizing their e-Portfolios, and giving the necessary information and explanations about using them. 


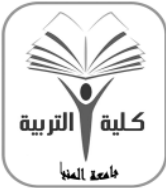

\section{مجالة البحثُ في التزبية ومعم الثفس \\ كايلةالتربية - جامعة المنيا \\ كلية مُتملةة من الميئة القومية لضمان جودةالتمليم}

5- Explaining why they need to develop an e-Portfolio.

6- Explaining how would they develop an e-Portfolio, (collect, select. reflect, connect, and collaborate).

7- Explaining how would they organize an e-Portfolio. (the entry or home page, main pages and subpages with reflections).

8- Informing participants on the basic concept of e-Portfolio and their responsibilities and reinforcing their skills in information communication technology (ICT).

9- Sticking to the following main steps in creating the e-portfolio: participants were instructed to:

- make sure that each one has a Gmail account.

- create an e-Portfolio through Google sites following these steps:

a. Going to Google page,

b. Then, going to Google Apps menu and choosing 'drive'.

c. When they are in their drive, they click on the 'new' button $\rightarrow$ more $\rightarrow$ then they choose Google sites.

d. Once the site is created, they name it (put the site name).

e. Then they name their page title.

f. After that, they can create and name the chapters according to the content of the course.

g. When the work is done and completed, each one has to publish his/her sites with their instructor and colleagues as well.

10- Writing the intended learning outcomes of the course in their e-Portfolios.

11- Introducing them gradually to e-Portfolio-work by giving small tasks, including exercises on the reflective process.

12- Using the rubric for helping students evaluate and reflect on performance on their e-Portfolios. Participants are required also to complete the rubric and answer the questions given.

13- Informing participants that the e-Portfolio program would include motivation features that will create a relaxed learning atmosphere, create student ownership and draw their attention to engage with their created work.

14- Giving the instructor's as well as peers' feedback on the ePortfolios during the course. 


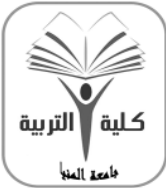

\section{مجالة البحثُ في التزبية ومعم الثفس \\ كايلةالتربية - جامعة المنيا \\ كايلة مُعتملة من الميئة القوميل لضمان جودة التمليم}

15- Letting them know from the very beginning what was to be assessed: (skills, learning, performance, products, oral and written tests, group-work, etc.). and providing the necessary guidelines.

16-Reflecting on participants' e-Portfolios to assure continuity and successful development of their learning.

17-Providing reliable reflective self-assessment tools such as the rubric.

18-Discussing and assessing the work done.

Findings

This study explored the effect of an e-Portfolio program on the development of reflective self assessment, motivation, and achievement of post graduates. The "t-test" was utilized for the analysis of data obtained from the reflective assessment scale, the motivation scale, and the achievement test. Scores of the participants on the pre-post performances were analyzed and compared

Hypothesis (1) predicted that the e-Portfolio program would develop the post graduates' reflective self assessment. Analysis of data using $t$ - test indicated that the study group's mean scores on the post reflective self assessment scale was higher and statistically significant compared to the pre- administration as t-values are: (17.08, 26.70, 15.48, 24.10, and 32.73, for planning, assessment/reflection, instruction, management and the total score, respectively). Eta-squared ( $(2)$ is $(0.97)$ as presented in Table (6). Consequently, the first hypothesis is confirmed and accepted.

Table ( 6 )

t-value $\& \eta^{2}$ Between Mean Scores of the study Group on the Pre-Post Reflective Self Assessment Scale

\begin{tabular}{c|c|c|c|c|c|c|c}
\hline \hline \multirow{2}{*}{ Dimensions } & \multirow{2}{*}{ Score } & \multicolumn{2}{|c|}{ Pre } & \multicolumn{2}{|c|}{ Post } & \multirow{3}{*}{ t-value } & \multirow{2}{*}{ )n2( } \\
\cline { 3 - 7 } & & Mean & SD & Mean & SD & & \\
\hline \hline Planning & 35 & 15.13 & 4.36 & 31.70 & 3.01 & $17.08^{* *}$ & \\
\hline Assessment / Reflection & 50 & 19.06 & 4.29 & 44.10 & 2.82 & $26.70^{* *}$ & \multirow{2}{*}{$0.97^{* *}$} \\
\hline Instruction & 40 & 19.93 & 5.52 & 37.16 & 2.57 & $15.48^{* *}$ & \\
\hline \hline
\end{tabular}

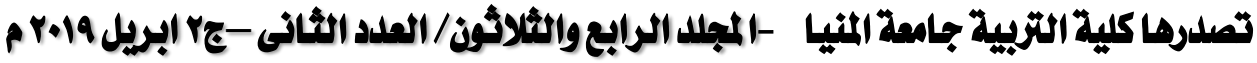




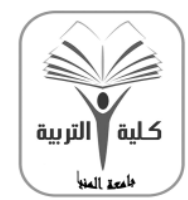

مجلة البعث في التزبية وعلم النفس

كلية التزبية - جامعة المنيا

كلية مُعتمدة من الهيئة القومية لشمان جودة التعليم

\begin{tabular}{c|c|c|c|c|c|c|c}
\hline \hline Management & 50 & 19.40 & 5.13 & 45.53 & 2.97 & $24.10^{* *}$ & \\
\hline Total Score & 175 & 73.70 & 12.46 & 158.50 & 6.78 & $32.73^{* *}$ & \\
\hline \hline
\end{tabular}

** Significant at $\mathbf{0 . 0 1}$

Hypothesis (2) predicted that the e-Portfolio program would develop the post graduates' motivation. Results revealed that the study group achieved a significant improvement on the post motivation scale as the obtained $t$-values, are $(23.49,25.12,34.12)$ in the motivation for e-portfolio, motivation for teaching and the total score of the scale, respectively, and $\eta^{2}$ is $(0.97)$. These results illustrate that the increase in the study group's motivation due to the exposure to the e-Portfolio program was found to be achieved. Consequently, the second hypothesis is accepted. See Table (7).

Table (7) t-value \& $\eta^{2}$ Between Mean Scores of the Study Group in the Prepost Motivation Scale

\begin{tabular}{|c|c|c|c|c|c|c|c|}
\hline \multirow[b]{2}{*}{ Dimensions } & \multirow[b]{2}{*}{ Score } & \multicolumn{2}{|c|}{ Pre } & \multicolumn{2}{|c|}{ Post } & \multirow[b]{2}{*}{ t-value } & \multirow[b]{2}{*}{)$\eta 2($} \\
\hline & & Mean & SD & Mean & SD & & \\
\hline Motivation for e-portfolio & 50 & 16.23 & 4.14 & 42.80 & 4.59 & $23.49 * *$ & \multirow{3}{*}{$0.97 * *$} \\
\hline Motivation for Teaching & 50 & 15.93 & 4.77 & 43.16 & 3.57 & $25.12 * *$ & \\
\hline Total Score & 100 & 9.13 & 7.31 & 24.83 & 4.78 & $34.12 * *$ & \\
\hline
\end{tabular}

Hypothesis (3) predicted that the e-Portfolio program would develop the post graduates' achievement. Results revealed that the study group achieved higher on the post achievement test as the difference in the mean scores between the pre and post test is statistically significant. The obtained $t$-value of the first dimension is (16.37), of the second is (14.77), of the third is (15.50), and of the total score is (29.31) and $\eta^{2}$ is (0.96). Consequently, the third hypothesis is accepted See Table (8).

Table ( 8 ) $t$-value $\& \eta^{2}$ between mean scores of the Study Group in the Pre-post Achievement Test

\begin{tabular}{|c|c|c|c|c|c|c|c|}
\hline \multirow{2}{*}{ Dimensions } & \multirow{2}{*}{ Score } & \multicolumn{2}{|c|}{ Pre } & \multicolumn{2}{|c|}{ Post } & \multirow[b]{2}{*}{ t-value } & \multirow[b]{2}{*}{)$\eta 2($} \\
\hline & & Mean & SD & Mean & SD & & \\
\hline $\begin{array}{l}\text { Characteristics of gifted and slow } \\
\text { learners }\end{array}$ & 10 & 3.20 & 1.21 & 8.53 & 1.30 & $16.37 * *$ & \multirow{4}{*}{$0.96^{* *}$} \\
\hline $\begin{array}{l}\text { Teaching Skills } \\
\end{array}$ & 10 & 2.96 & 1.03 & 8.13 & 1.61 & $14.77 * *$ & \\
\hline Management & 10 & 8.16 & 1.15 & 3.10 & 1.36 & $15.50 * *$ & \\
\hline Total & 30 & 9.13 & 1.99 & 24.83 & 2.15 & $29.31 * *$ & \\
\hline
\end{tabular}

**Significant at 0.01

Discussion

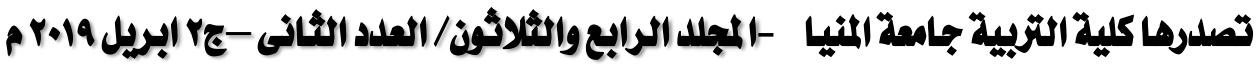




\section{مجالة البحثَ في التزبية وملم النفس \\ كاية التزبية - جامعة المنيا \\ كبلة مُتملةمن الميئة القومية لشمان جودةالتمبيم}

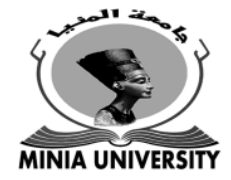

The present study investigated the use of an e-Portfolio program for developing reflective self assessment, motivation, and achievement of post graduate English majors at the Faculty of Education-Minia University. Results of the study show that there are statistically significant differences between the means of the study group's scores on the pre-post administration of the instruments in favor of the post applications. This indicates that the participants' self assessment, motivation, and achievement have been developed.

The participants' scores on the pre-applications were not convincing. Before implementing the e-Portfolio program, their performance showed that they were in need of such a program. Consequently, training them through the e-Portfolio program gave them enough opportunity to fill the gap in their preparation and to score higher on the post applications.

Benefits of conducting the e-Portfolio program were derived from the exchange of ideas and feedback between the creator and owner of the e-Portfolio and those who view and interact with it. The students' personal reflection on the work inside an e-Portfolio helped to create a meaningful learning experience. This goes with what is expressed by (Greenberg 2004).

Thus, the e-Portfolio proved to be an effective approach for post graduates. The participants reported that e-Portfolio enabled them to improve their ability to evaluate themselves. Some participants reported having received study materials from their instructor which helped them to perform well. Thus the participants reported positive results in performance as a result of getting data and creating portfolios online. Students indicated personal pride in their reflections on their work and accomplishments, and make mention of enjoying certain challenges posed by work online. Through reflection, which was a requirement of the e-portfolios, students identify personal weakness in their development and mention learning strategies that might be applied in order to make progress in their learning. The results may have also been affected by the continuous and periodical reflection on their own work as a means of improving their products. These findings agree with those obtained by Rhodes (

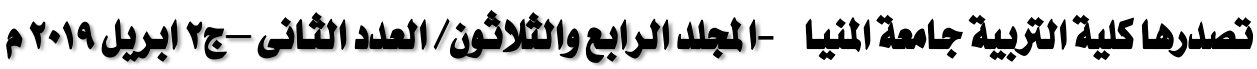




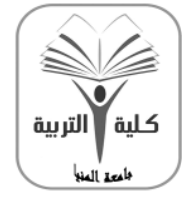

\section{مجالة البحثَ في التزبية وملم النفس \\ كاية التزبية - جامعة المنيا \\ كلية مُعتملة من الميئة القومية لشمان جودة التمليم}

2011), and Lin (2008). In the present study also, e-Portfolio could increase the motivation of students. Literature review about motivation as related to the use of e-Portfolios revealed their good impact on motivation. To learn how to become reflective practitioners, post graduates need to acquire specific knowledge and skills, some of which greatly depend on the internet.

The use of e-Portfolio in higher education has become increasingly prevalent (Rhodes, Chen, Watson \& Garrison 2014). Further, there is an interest in e-Portfolios amongst educators in general, driven by the belief that e-Portfolios may evoke unique reactions from students (Buyarski \& Landis 2014). The results obtained from the reflective self assessment scale cope with those in a study by Strivens et. al. (2009), which reviewed the role of the portfolio as an assessment tool, and found that a number of respondents had carried out formal evaluations, gave a range of benefits relating both to student education and improved efficiency. The evaluations from students were equally positive. This work suggests that portfolios can be used successfully for assessment.

Self reflection played a basic role in the successful implementation and outcomes of the e-Portfolios. This goes with Stefani et al. (2007) who mentioned that "Reflection is an essential feature of a deep approach to learning. Structuring the practice of reflection transforms it into learning experience". E-portfolio software could allow for various activities that support this learning style. For example, at the beginning of the course, the students could be asked to reflect on what they did not know, what they would like to learn, and how they want to go about it. Students could keep a learning record throughout the course to record their thoughts, observations, feelings, and questions.

The aim of developing reflective teachers was to encourage students to be self-aware, self-critical; honest about themselves, and open to criticism and feedback. An e-Portfolio with reflective processes could develop these qualities in students. Due to the limitations of computer and internet access in the university, the learning took place at home or at any cyber. However, based on the results from the reflective self assessment scale, students did not see this as the main difficulty but were more challenged by the

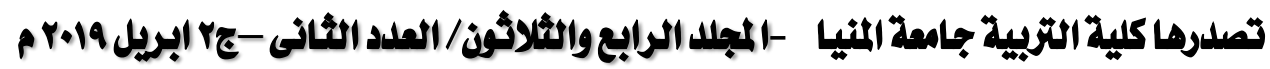

gamel_abdo59@yahoo.com

http://ms.minia.edu.eg/edu/journal.aspx 


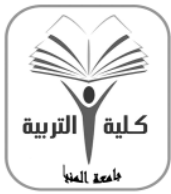

\section{مجالة البحثَ في التزبية وملم النفس \\ كاية التزبية - جامعة المنيا \\ كيلة مُتملةة من الميئة القومية لضمان جودةالتمليم}

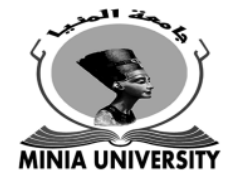

fact that they did not have previous knowledge about e-Portfolios and did not understand how they could learn teaching in a new way with e-Portfolios. When the researcher explained how to develop and create an e-Portfolio, the students were able to discuss and adjust their e-Portfolios in the class with their peers and the researcher. Providing advice and guidance to students throughout the course and giving feedback on the e-Portfolios, was invaluable as a means of increasing students' understanding of their own learning.

Using e-Portfolios allowed students to begin their learning at many different starting points. Formative feedback challenged the student's original insights prompting reflection and revision. In this sense, the e-Portfolio was a tool to support the process of learning, and assessment. Jackson (2003) believes that instructors should encourage students to construct new knowledge rather than to show how much transmitted knowledge they have retained. This is a 'constructivist' view, one which is very important in teaching and learning.

In the present study also, the researcher noted that not all of the ePortfolios were excellent; some were incomplete and should be better. However, the teaching and learning processes could benefit from using e-Portfolios by making the students active participants of their own learning. Using the online technology allowed the students to build their own e-Portfolios which they could keep after finishing their studies. It was important to create a rubric not for assessing an e-portfolio but for giving each student an opportunity for assessing his/her individual artifacts before sharing them.

At the end of the program, it was found that it succeeded in motivating the students to learn. Electronic videos, the different artifacts collected online and charts seemed to be an incentive motivation that encouraged students to work harder. Results of a study by Jessie (2016) indicate that online based portfolios had a positive impact on students' practices, making it an effective tool for assessment.

Students' motivation was relevant since it potentially affected the way they work with and view the e-Portfolio. Motivation provided

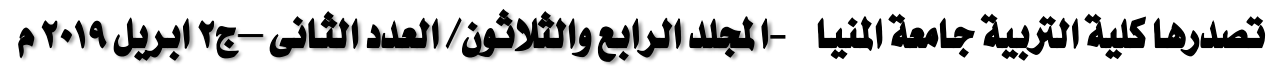

gamel_abd059@yahoo.com

http://ms.minia.edu.eg/edu/journal.aspx 


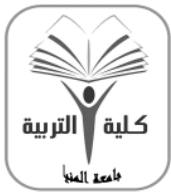

\section{مجالة البحثَ في التزبية ومام النفس \\ كاية التزبية - جامعة المنيا \\ كلية مُتملةة من الميئة القومية لضمان جودةالتمليم}

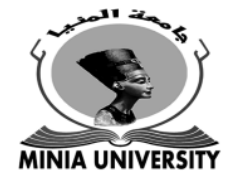

a basis for predicting what factors promoted versus negated students' perceptions of the effectiveness of the e-Portfolio in supporting self assessment and is important to understanding why and how they engage with and evaluate e-Portfolio's use in the context of promoting achievement.

Although the e-Portfolio offered clear advantages over the traditional one, this brought corresponding challenges such as maintaining the security of the information in the e-Portfolio, providing technical and academic support, giving feedback to students, intellectual property rights, technical skills, understanding what e-Portfolios are and how to create one, spending a lot of time focusing on the design rather that on the content, lack of self assessment, reflection, and technology skills in students' educational background. Students' ownership of their ePortfolios was another motivating factor. The e-Portfolio could promote this sense of ownership. It allowed students to take control, to add and make changes to their personal information, and to select what they feel was suitable to their learning.

The e-Portfolios also could add to the achievement level of the participants. This was clear in the results of the achievement test. This agrees with a study by Tubaishat and Lansari (2013) whose results show that students have a positive attitude towards ePortfolio to help them store their work and to document the achievement of specific learning outcomes. Students feel that they improved their learning experiences through the use of reflection. They also believe that using their e-Portfolios allows them to better manage their learning. The study also found that about half the students actually enjoyed having to develop and maintain their e-Portfolios to show achievement of various learning goals. Participants' Reactions

1-The students emphasized that the e-portfolio was valuable as a personal developmental learning tool.

2- The e-portfolio gave them a chance to find out about the skills they should be learning in college and there are ways that they can keep track of how they are doing.

3- Examples of reflections are : (I realized that my work in my eportfolio is a reflection of my personality and that my identity had

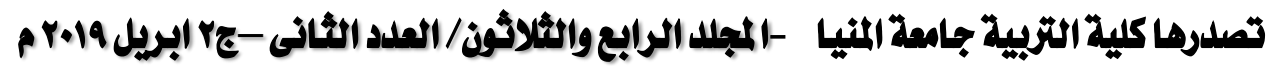

gamel_abdo59@yahoo.com

http://ms.minia.edu.eg/edu/journal.aspx 


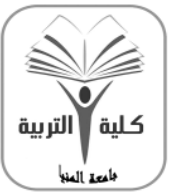

\section{مجالة البحثَ في التزبية ومام النفس \\ كاية التزبية - جامعة المنيا \\ كلية مُعتمدة من الميئة القومية لضمان جودة التمليم}

played a part in my learning), ( I have gained technical skills, and I have learned to express myself as a graduate student), (the different sections of my e-portfolio made me realize how I see myself now and in my future). (When I had a chance to reflect on my work and was asked to describe the experience to others, I realized that I had a lot more than I thought), (an e-portfolio is a new learning experience for me), (It has made me more interested in my work with the course), (It helps me think more about my own learning), ( It helps me to be organised), (It Increases my confidence), ( It was easy because I received the support I needed), ( I have achieved more than I expected through working on my e-portfolio and from sharing it with my instructor and my friends).

\section{Recommendations of the Study}

Depending on the significant results of the present study regarding the effect of the e-portfolio program on students' reflective self assessment, motivation, and achievement, the researcher highly recommends:

1- Continued training on the use of e-portfolios to ensure the achievement of learning in general.

2- Future research should focus on social outcomes such as self-esteem and confidence, and the ways by which individual and collective creativity can be supported by ePortfolio systems.

3- E-Portfolio is recommended to be used as an effective assessment tool of students' achievement in different courses.

Suggestions for Further Research

The researcher recommends that further research be conducted in the following areas:

1. Studying the role of e-Portfolio in the learning process.

2. Investigating the effects of e- Portfolios on heightening selfesteem, self satisfaction, and attitudes.

3. Replicating the present study with a larger group.

4. Replicating the present study with different variables such as self regulation, self efficacy, etc.

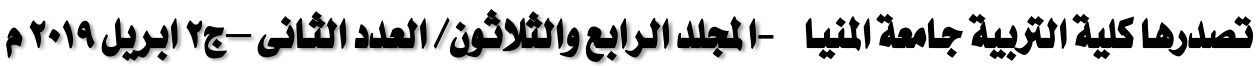

gamel_abdo59@yahoo.com

http://ms.minia.edu.eg/edu/journal.aspx 


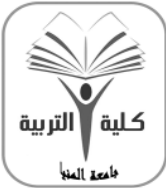

\section{مجالة البحثُ في التزبية ومعم الثفس \\ كايلة التزبية - جامعة المنيا \\ كلية مُتملدة من الميئة القومية لضمان جودةالتمعيم}

5. Using e-Portfolios for assessing student's personal and professional development.

6. Investigating the effect of e-Portfolio satisfaction on students' self-efficacy.

Conclusion:

The findings of the study reflect the utility of the e-Portfolio program for developing students' reflective self assessment, motivation, and achievement. Students highlighted the benefits of using the e-Portfolio program as a useful tool for enhancing their reflective self assessment, motivation, and achievement. They indicated that they enjoyed the online work of creating the ePortfolio which was very stimulating, interesting and motivating. They were pleased for having enough opportunity to communicate and cooperate with their colleagues. Meeting online increased their motivation which, in turn, developed their self assessment, and achievement. Providing students with clear and obvious instructions before creating their e-Portfolios fostered their understanding of the necessity of receiving training online. There is evidence that providing supportive feedback throughout the program was highly appreciated by the participants as revealed in their reflections. Results gained from analysis of data were good indicators of the utility of the e-Portfolio program on the students' self assessment, motivation, and achievement. The e-Portfolio itself was not to be assessed but the artifacts created were graded. Each week the students were given an activity to complete which they could then upload to their e-Portfolios. Each session focused on a different topic for the student to show their learning and to develop their technology skills. They liked to show their videos, and presentations among other artifacts uploaded. 


\section{مجلة البهث في التربية وعلم النفس \\ كلية التربية - جامعة المنيا \\ كالية مُتمدة من الهيئة القومية لشمان جودة التعليم}

\section{Reierences}

Abrami, P. C., \& Barrett, H. (2005). Directions for Research and Development on Electronic Portfolios. Canadian Journal of Learning and Technology, 31(3). Online version.

Ahn, J. (2004). Electronic portfolios: Blending technology, accountability and assessment. Retrieved July 16, 2018, from http://thejournal.com/articles/16706

Alexiou, A., \& Paraskeva, F. (2010). Enhancing self-regulated learning skills through the implementation of an e-portfolio tool. Procedia-Social and Behavioral Sciences, 2(2).

Andre, K.E. (2011). Nursing and midwifery portfolios: evidence of continuing competence. Australia: Elsevier.

Apple, M. \& Shimo, E. (2004). Learners to teacher: portfolios, please! Perceptions of portfolio assessment in EFL classrooms. The Interface between Interlanguage, Pragmatics and Assessment: Proceedings of the 3rd Annual JALT Pan-SIG Conference. .53-58.

Axton, K. J.(2012). The Role of Portfolios in Student Motivation. V I S I O. (42), 23-42.

Barrett, H.C. (2004). Electronic Portfolios as Digital Stories of Deep Learning.https://electronicportfolios.com/digistory/epstory.html (last accessed 20 November 2018).

Barrett, H. C. (2006). "White paper: Researching Electronic Portfolios and Learner's Engagement. [Retrieved November 5, 2007

Barrett ,H.C (2011). Balancing the two faces of e-Portfolios. In S Hirtz \& K Kelly (eds). Education for a digital world: innovations in education (2nd ed). Victoria, BC: British Columbia Ministry of Education. .

Barton, J., \& Collins, A. (1997). Starting out: Designing your portfolio. In Barton, J \& Collins, A. (Eds.), Portfolio Assessment: A handbook for educators (1-10).

Bass, R., \& Eynon, B. (2009) Capturing visible evidence of invisible learning Academic Commons, January, www.academiccommons. org/issue/january- 2009 NJ: Dale Seymour Publications.

Biggs, J., \& Tang, C. (2011). Teaching for quality learning at university. Berkshire: McGraw-Hill International.

Boulton, H. \& Hramiak, A.(2012). E-flection: the development of reflective communities of learning for trainee teachers through the use of shared online web logs. Reflective Practice, 13 (4), 503-515.

Boulton, H. (2014). E-Portfolios beyond pre-service teacher education: A new dawn? European Journal of Teacher Education, 37(3), 374-89.

Brown, J. (2002). Know thyself: the impact of portfolio development on adult learning. Adult Education Quarterly, 52 (3), 228-245. 

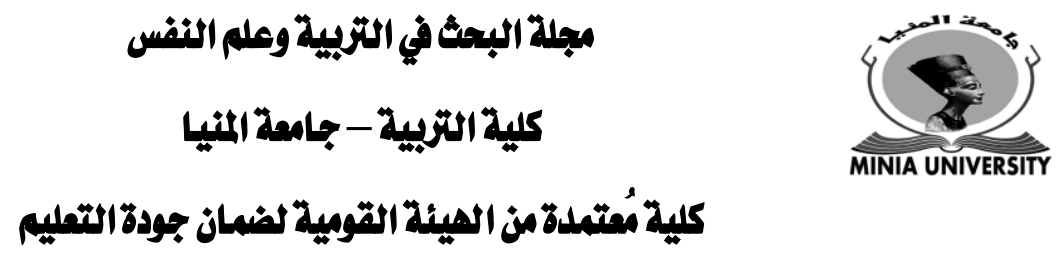

Buckley,S; Coleman J et al (2009) The educational effects of portfolios on undergraduate student learning: a Best Evidence Medical Education (BEME) systematic review. Medical Teacher, 31(4), p. 282-298.

Cambridge, D. (2010). E-portfolios for lifelong learning and assessment. San Francisco, CA: Jossey-Bass.

Canada, M. (2002). Assessing e-folios in the on-line class. New Directions for Teaching and Learning (91), 69-75.

Challis, D. (2005). Towards the mature e-Portfolio: Some implications for higher education. Canadian Journal of Learning and Technology, 31(3), online version.

Chang, C. C., Liang, C., Tseng, K. H., \& Tseng, J. S. (2014). Using e-portfolios to elevate knowledge assessment among university students. Computers \& Education, 72, 187195.

Chaudhuri, T. \& Cabau, B.(2017). E-Portfolios in Higher Education: AMulti disciplinary Approach (1st ed. )Springer.2017.

Cowan, J. \& Peacock, S. (2017). Integrating reflective activities in eportfolios to support the development of abilities in self-managed experiential learning, Reflective Practice, 18(5), 655.

Dikici, A. (2009). An Application of Digital Portfolio with the Peer, Self and Instructor Assessments in Art Education. Eurasian Journal of Educational Research, 36, 91-108.

Dörnyei, Z. (2005) The psychology of the language learner; Individual differences in second language acquisition. Mahwah, NJ: Lawrence Erlbaum Associates, Inc.

Driessen, E.W.; van Tartwijk J. (2005a) Conditions for successful reflective use of portfolios in undergraduate medical education. Medical Education 39:1230-1235.

Driessen, E. W., Muijtjens, A. M., van Tartwijk, J., \& van der Vleuten, C. P. (2007). Web- or paper-based portfolios: Is there a difference? Medical Education, 41(11), 1067-1073.

Epstein, A. (2009). Designing and Implementing a Portfolio Program. Synapse Learning Design. Retrieved April 7, 2009 from Expeditionary Learning Schools Outward Bound web site.

Eynon, B. \& Gambino, L. M. (2017). High-impact e-Portfolio practice: A catalyst for student, faculty and institutional learning. Sterling, VA: Stylus.

Finley, A. (2012). Making progress? What we know about the achievement of liberal outcomes. Washington, DC: Association of American Colleges and Universities.Galy, E.,

Gámiz-Sánchez, V-M., Gallego-Arrufat, M-J., \& Crisol-Moya, E. (2016). Impact of electronic portfolios on prospective teachers' participation, motivation and autonomous learning. Journal of Information Technology Education: Research, 15, 517-533. 


\section{مجلة البعث في التزبية وعلم النفس \\ كلية التزبية - جامعة المنيا \\ كالية مُمتعدة من الهيئة القومية لضمان جودةالتصليم}

Goldsmith, D. J. (2007). Enhancing learning and assessment through e portfolios: A collaborative effort in Connecticut. New Directions for Student Services, 119, 31-42.

Gordon, J. (2003). Assessing student's personal and professional development using portfolios and interviews. Medical Education, 37, 335-340.

Gray, L. (2008). Effective practice with e-portfolios. JISC, 5-40.

Greenberg, G. (2004). The digital convergence: Extending the portfolios model. Educause Review, 39(4), 28-36.

Wimmer, M. B. and Ziegler, A. (2018). E-portfolio use and its effects on exam performance - a field study. Studies in Higher Education - August 2018.

Hart, H. (2015). The use of Weblog with a Facebook Login for Portfolio Assessment in an English writing Class: A Practical Model. Conference Paper.

Heath, M. (2002). Electronic portfolios for reflective self-assessment. Teacher Librarian, 30(1), 19-23.

Heath, M. (2005). Are you ready to go digital? The pros and cons of electronic portfolio development. Library Media Connection, 23(7), 66-70.

Huang, J.S.; Yang, J.H.; and Chang, M. C.W. (2011) "The Effect of e-Portfolio Satisfaction on Students' Learning Motivation and Internet Selfefficacy," Journal of Educational Technology Development and Exchange (JETDE): 4 (1).

Irie, K. (2005). Stability and flexibility of language learning motivation: a multimethod study of Japanese junior high school student Unpublished doctoral dissertation, Temple University, Philadelphia.

Issenberg,S.B; McGaghie, W.C. (2002). Clinical skills training - practice makes perfect. Medical Education; 36: 210-211.

Jessie, S. B. (2016). Using Facebook-based e-portfolio in ESL writing classrooms: impact and challenges, Language, Culture and Curriculum, 29(3).

Kennedy, D. \& Shirley, C. (2011). Innovative curriculum design: Using ePortfolios to change practice and process. Proceedings of Global Learning 2011, 409-416.

Lawrence, S. (2017). Using e Portfolios to record achievement. Teaching And Learning with technology. Online at http://instructionaldesign.ucc.ie/2017/03/22/using-eportfolios/

Ligorio, M. \& Sansone, N. (2009). Structure of a Blended University Course: Applying Constructivist principles to blended Teaching Information Technology and Constructivism in Higher Education: Progressive Learning Frameworks, 216-230 Available From https://www.researchgate.net/ publication/262525013.

Lin, Q. (2008). Preservice teachers' learning experiences of constructing eportfolios online. Internet and Higher Education, 11, 194-200. 


\section{مجلة البعث في التزبية وعلم النفس \\ كلية التزبية - جامعة المنيا \\ كالية مُمتعدة من الهيئة القومية لضمان جودةالتعليم}

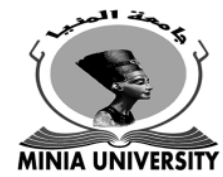

Lorenzo, G., \& Ittleson, J. (2005c).Demonstrating and assessing student learning with e-portfolios. Retrieved from http://www.educause.edu/LibraryDetailPage/666?ID=ELI30

Milman, N. (2005). Web-based digital teaching portfolios: fostering reflection and technology competence in preservice teacher education students. Journal of Technology and Teacher Education, 13 (3), 373-396.

Moon, J. (2005). Guide for busy academics no. 4: Learning through reflection. The Higher Education Academy.

Murie J; Wakeling J (2011). Verification of 'learning credits' by GP appraiser. Education for Primary Care, 22, 369-376.

Orland-Barak, L. (2005). Portfolios as evidence of reflective practice: What remains 'untold'. Educational Research, 47 (1), 25-44.

Paris, S. G., \& Ayers, L. R. (1994). Becoming reflective students and teachers with portfolios and authentic assessment. Washington, DC: American Psychological Association.

Pegrum,M. and Oakley, G.(2017). The Changing Landscape of E-Portfolios: Reflections on 5 Years of Implementing E-Portfolios in Pre-Service Teacher Education. from book E-Portfolios in Higher Education. A Multidisciplinary Approach (21-34)

Pitts J; Thomas,C. A (2001). Enhancing reliability in portfolio assessment: 'shaping' the portfolio. Med. Teach. 23, 351-355.

Plata, S. M. (2003). Portfolios, learning logs, and checklists. Guidelines, 25 (2), $15-20.15$

Reese, M., \& Levy, R. (2009). Assessing the future: E-portfolio trends, uses, and options in higher education. ECAR Research Bulletin, (4),1-12.

Rhodes, T. L. (2011). Making learning visible and meaningful through electronic portfolios. Change, 6-13.

Rowley, J. and Munday, J. (2018). The evolved landscape of e-Portfolios: Current values and purposes of academic teachers and curriculum designers. Available fromhttps://www.researchgate.net/publication/323272279.

Ryan, R. M.; Deci, E.L. (2000).Intrinsic and Extrinsic Motivations: Classic Definitions and New Directions". Contemporary Educational Psychology. 25 (1): 5467.

Schneider, C. G., \& Rhodes, T. L. (2011). Forward. In R. J. Sternberg, J. Penn, \& C. Hawkins (Eds.), Assessing college student learning: Evaluating alternative models, using multiple methods. Washington, DC: Association of American Colleges and Universities.

Sherry, A. C., \& Bartlett, A. (2005). Worth of electronic portfolios to education majors: A 'two by four' perspective. Journal of Educational Technology Systems, 33(4), 399-419.

Singer-Freeman, K. E., Bastone, L. \& Skrivanek, J. (2016). Using e Portfolios to assess applied and collaborative learning and academic identity in a summer research 


\section{مجلة البعث في التزبية وعلم النفس \\ كلية التزبية - جامعة المنيا \\ كالية مُتمدة من الهيئة القومية لشمان جودة التعليم}

program for community college students. International Journal of e-Portfolio, $6(1), 45-57$.

Smith, K., \& Tillema, H. (2001). Long-term influences of portfolios on professional development. Scandinavian Journal of Educational Research, 45(2), 183-203.

Smith, K., \& Tillema, H. (2003). Clarifying different types of portfolio use. Assessment and Evaluation in Higher Education, 28(6), 625- 648.

Stefani, L., Mason, R., \& Pegler, C. (2007). The educational potential of eportfolios: Supporting personal development and reflective learning. London \& New York, NY: Routledge.

Stefanie Y. Chye • Albert K. Liau • Woon Chia Liu (2012).. Student Teachers' Motivation and Perceptions of E-Portfolio in the Context of ProblemBased Learning. Asia-Pacific Edu Res (2013) 22(4):367-375.

Strudler, N. and Keith Wetzel, K. (2011). Electronic Portfolios in Teacher Education: Forging a Middle Ground. Journal of Research on Technology in Education, 44 (2), 161-173.

Topp, N.W., Clark, P. \& Goeman, R. (2002). Web-based electronic portfolios: A Systemic approach. In D. Willis et al. (Eds.), Proceedings of Society for Information Technology \& Teacher Education International Conference 2002 (549-550).

Trevitt,A.C. Macduff,A. and Steed,A (2014). practice development Agenda ahead[e]portfolios for learning and as evidence of achievement: Scoping the academic practice development agenda ahead. in The Internet and Higher Education 20:69-78.January 2014 DOI: 10.1016/j.iheduc.2013.06.001

Tubaishat , A.\& Lansari,A.(2013). Using Student e-Portfolios to Facilitate Learning Objective Achievements in an Outcome-Based University. Journal of Information Technology Education: Innovations in Practice. $12,113-127$.

Tuksinvarajarn, J., and Sojisirikul, P. (2009 ). Adding Motivation Features to Electronic Portfolios: A Case Study at KMUTT. Proceedings of the TESOL Arabia Conference "Finding your Voice: Critical Issues in ELT". 331 - 342 . 


\section{مجلة البعث في التزبية وعلم النفس \\ كلية التزبية - جامعة المنيا \\ كالية مُتمدة من الهيئة القومية لشمان جودة التعليم}

Uí Choistealbha, J. (2018). The benefits and challenges of using e Portfolios. In I. Kunnari \& M. Laurikainen (eds.) Students' perspectives in e-Portfolios. HAMK Unlimited Journal 31.1.2018.

Ushioda, E. (2008). Motivation and good language learners. In C. Griffiths (Ed.), Lessons from good language learners. Cambridge: Cambridge University Press.

Vance G; Williamson, A et al (2013) Evaluation of an established learning portfolio. The clinical teacher, 10(1), 21-26

Voogt, J., Erstad, O., Dede, C. \& Mishra, P. (2013). Challenges to learning and schooling in the digital networked world of the 21st century. Journal of computer assisted learning, 29(5), 403-413.

Wade, A., Abrami, P. C., \& Sclater, J. (2005). An electronic portfolio to support learning. Canadian Journal of Learning and Technology, 31(3), online version.

Wang, C. K., Hagger, M., \& Liu, W. C. (2009). A cross-cultural validation of perceived locus of causality scale in physical education context. Research Quarterly for Exercise and Sport, 80 (2), 313-325.

Willis, L., and Wilkie, L. (2009). Digital career portfolios: expanding institutional opportunities. Journal of Employment Counseling, 46, 73-81.

Wray, S. (2007). Electronic Portfolios in a Teacher Education Program. Learning 4(1).

Yang, N. D. (2003). Integrating portfolios into learning strategy-based instruction for EFL college students. International Review of Applied Linguistics, 41(4), 293-317.

Yancey, K. B. (2001). Digitized student portfolios. In B. L. Cambridge, S. Kahn, D. P. Tomplins \& K. B. Yancey (Eds.), Electronic portfolios: Emerging practices in student, faculty, and institutional learning (1530). Washington, DC: American Association for Higher Education.

Young, J. R. (2002). 'E-portfolios' could give students a new sense of their accomplishments. Chronicle of Higher Education, 48 (26), A31-A32.

Zeichner, K., \& Wray, S. (2001). The teaching portfolio in US teacher education programs: What we know and what we need to know. Teaching and Teacher Education, 17(5), 613-621. 